\title{
Direct methane and nitrous oxide emissions of South African dairy and beef cattle
}

\author{
C.J.L. du Toit ${ }^{1,3 \#}$, H.H. Meissner ${ }^{2} \&$ W.A. van Niekerk ${ }^{3}$ \\ ${ }^{1}$ Department of Animal Science, Tshwane University of Technology, Private Bag X680, Pretoria, 0001, South Africa \\ ${ }^{2} 189$ van Riebeeck Avenue, Lyttelton Manor, Centurion, 0157, South Africa \\ ${ }^{3}$ Department of Animal and Wildlife Sciences, University of Pretoria, 0002, South Africa
}

Copyright resides with the authors in terms of the Creative Commons Attribution 2.5 South African Licence.
See: http://creativecommons.org/licenses/by/2.5/za
Condition of use: The user may copy, distribute, transmit and adapt the work, but must recognize the authors and the South African Journal of Animal
Science.

\begin{abstract}
The objective of this study was to estimate direct methane and nitrous oxide emissions of South African dairy and beef cattle in total and per province using the Tier 2 methodology of the Intergovernmental Panel on Climate Change (IPCC), but adapted for tropical production systems. Dairy and beef cattle in 2010 contributed an estimated 964 Giga gram (Gg) or $72.6 \%$ of the total livestock methane emissions in South Africa. Beef cattle in extensive systems were the largest contributor (83.3\%), followed by dairy cattle (13.5\%), and feedlot cattle (3.2\%). The enteric methane emission factors for dairy cattle of $76.4 \mathrm{~kg}$ $\mathrm{CH}_{4} /$ head/year and $71.8 \mathrm{~kg} \mathrm{CH} /$ head/year for concentrate fed and pasture-based production systems, respectively, were higher than those reported by other developing countries, as well as the IPCC default value of $46 \mathrm{~kg} \mathrm{CH} / \mathrm{head} /$ year for developing countries. The beef cattle methane emission factors of $78.9 \mathrm{~kg}$ $\mathrm{CH}_{4} /$ head/year and $62.4 \mathrm{~kg} \mathrm{CH} /$ head/year for commercial and emerging/communal cattle, respectively, were similar to those reported by other developing countries, but higher than the IPCC default value of 31 $\mathrm{kg} / \mathrm{head} /$ year. Primarily because of cattle numbers, Eastern Cape recorded the highest dairy and beef cattle methane emissions, whereas Gauteng showed the highest feedlot methane emissions.
\end{abstract}

Keywords: Greenhouse gas, production systems, commercial, communal, feedlot, rangeland

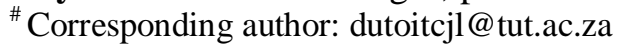

\section{Introduction}

Recently South African livestock producers have come under increasing pressure over the environmental impact of production systems. The FAO (2006) reported that livestock contributed an estimated $18 \%$ of global anthropogenic greenhouse gas (GHG) emissions. Livestock produce GHG's in the form of methane $\left(\mathrm{CH}_{4}\right)$ from enteric fermentation, and nitrous oxide $\left(\mathrm{N}_{2} \mathrm{O}\right)$ and methane from manure management and manure deposited on pastures and veld (rangeland) by grazing animals. Agriculture, forestry and land use (corrected for carbon sink values) emitted an estimated 4.9\% of South African GHG gases in 2004, which makes it the third largest GHG contributor in South Africa after the energy industry and industrial processes with $78.9 \%$ and $14.1 \%$, respectively (DEAT, 2009). Livestock produced approximately $27 \%$ of the national methane gas total, mainly through enteric methane emissions from ruminants. Otter (2010) reported that livestock contributed 98\% of the agricultural sector's methane emissions. Methane is a potent GHG that remains in the atmosphere for approximately 9 to 15 years and is 25 times more effective in trapping heat in the atmosphere than $\mathrm{CO}_{2}$ over a 100-year period (FAO, 2006; IPCC, 2006). Nitrous oxide has an atmospheric lifetime of 150 years and a global warming potential of 296 times that of $\mathrm{CO}_{2}$ (IPCC, 2006).

O’Mara (2011) stated that livestock GHG emissions relate closely with ruminant numbers, particularly cattle. In 2004, commercial beef cattle contributed $45 \%$ and emerging/communal cattle $33 \%$ of the total enteric fermentation of 1225 Giga gram (Gg) $\mathrm{CH}_{4}$ in South Africa with mature cows and bulls having the highest $\mathrm{CH}_{4}$ emission factors for enteric fermentation (Otter, 2010). 
South African livestock production is based on a unique combination of commercial (intensive and extensive) and emerging and communal (subsistence) production systems. The levels of productivity and efficiency in these production systems vary greatly in certain areas and it is important to distinguish between them when calculating GHG emissions. Methane production in livestock is influenced by several factors other than population numbers, including the size and productivity of animals, level of feed intake, diet composition, digestibility and quality of forage, forage species and cultivar, as well as variation among animals (Scholtz et al., 2012).

Previous inventories (Blignaut et al., 2005; DEAT, 2009; Otter, 2010) were conducted on a national scale utilizing IPCC default values (Tier 1 approach) for some or all of their emission calculations. These emission factors do not distinguish effectively between classes of animals, production efficiencies, and production systems. They are often based on assumptions of animals utilizing highly digestible diets as well as temperate forages (Mills et al., 2001) which are not representative of South African production systems.

It is important to generate accurate GHG baseline figures to develop South Africa's capacity to understand and reduce GHG emissions from the livestock sector. The objective of this paper, therefore, is to re-calculate the direct methane and nitrous oxide emissions of dairy and beef cattle production in South Africa, taking into consideration the uniqueness of the South African scenario and using a refined Tier 2 approach. The Tier 2 methodology seeks to define animals, animal productivity, diet quality and management circumstances to support a more accurate estimate of feed intake for use in estimating methane production from enteric fermentation (IPCC, 2006). It was also considered important to do separate calculations for provinces as provinces differ in vegetation or biomes and production systems which may require different approaches to mitigation recommendations.

\section{Materials and Methods}

The methodology utilized is based on the Australian national greenhouse account's National Inventory Report (ANIR, 2010), which contains Australian country-specific and IPCC default methodologies and emission factors. Emission factors specific to South African conditions and management systems were calculated where possible. A Tier 2 approach was adopted for all major cattle sectors, including dairy, beef and feedlot, in accordance with the Intergovernmental Panel on Climate Change (IPCC, 2006) good practice requirements. The inventory was compiled on a provincial basis to reduce errors associated with averaging input data across areas with environmental, physical and managerial differences. The provincial totals were aggregated to produce national totals and the inventory was based on 2010 population data.

\section{Enteric fermentation}

The proportion of intake that is converted into methane is dependent on the characteristics of the animal, the quality and type of feed and the feed intake. South Africa is a country with diverse rainfall, temperature and soil patterns (Smith, 2006), which gives rise to regional and seasonal variations in feed quality and quantity. Due to the heterogeneity of available feed types within South Africa it was considered important to use methodologies that could reflect such differences and was developed under similar conditions as in Australia (ANIR, 2009).

\section{Dairy cattle}

Emissions from dairy cattle are based on commercial production systems. Cattle used for milk production in the emerging and subsistence farming sectors were incorporated under communal beef cattle emissions, since the milk yields are not high enough to meet the definition of a dairy cow. Data on provincial cow population figures and average daily milk production $(10.5 \mathrm{~kg} /$ day) were sourced from the commercial dairy industry and calculated from the number of dairy producers per province and the number of cows per producer (LACTO data, 2010). These figures were verified against the total annual milk production in 2010 ( 2.5 billion litres). The total number of dairy animals per province was then calculated according to the ideal herd composition of a 100 cow herd (Wasserman, 2005).

There are two major dairy production systems in South Africa, a total mixed ration (TMR)-based system and a pasture-based system. The liveweights of all classes of animals according to the herd structure was calculated according to data reported by Banga (2009) for Holstein cattle and Jersey cattle in TMRbased and pasture-based production systems. Banga (2009) reported that the national commercial dairy herd is composed of approximately $60 \%$ Holstein-type breeds and $40 \%$ Jersey-type breeds. This ratio was utilized 
to calculate the liveweight of animals used in the emission calculations. Liveweights of animals per age group were confirmed by using a prediction equation according to the Von Bertalanffy growth function given by Bakker \& Koops (1978) as:

$\mathrm{LW}(\mathrm{kg})=\mathrm{M}\left[1-\left\{1-\left(\mathrm{W}_{0} / \mathrm{M}\right)^{1 / 3}\right\} \mathrm{e}^{-\mathrm{kt}}\right]^{3}$

Where:

$$
\begin{aligned}
& \mathrm{LW}=\text { liveweight } \\
& \mathrm{M}=\text { mature weight }(\mathrm{kg}) \\
& \mathrm{W}_{0}=\text { birth weight }(\mathrm{kg}) \\
& \mathrm{k}=\text { growth rate parameter } \\
& \mathrm{t}=\text { age (months). }
\end{aligned}
$$

Variables used in the above equation were sourced from Banga (2009) and dairy breed societies in South Africa. Parameters used to predict the liveweight of the various classes of animals as reported by Banga (2009) are presented in Table 1.

Table 1 Parameters used to predict liveweight for each breed type and production system (Banga, 2009)

\begin{tabular}{lcccc}
\hline & \multicolumn{2}{c}{ Concentrate } & \multicolumn{2}{c}{ Pasture } \\
\hline & Holstein & Jersey & Holstein & Jersey \\
\hline Birth weight $(\mathrm{kg})$ & 40 & 30 & 40 & 30 \\
Mature weight $(\mathrm{kg})$ & 650 & 500 & 600 & 450 \\
Growth rate $(k)$ & 0.0885 & 0.0915 & 0.07625 & 0.089 \\
\hline
\end{tabular}

The animal weight, weight gain, diet characteristics and management data used in the algorithms to calculate emissions are presented in Appendix A. Daily methane production was calculated according to the Australian National Inventory Report (ANIR, 2009) based on dry matter intake.

Dry matter intake (I) for each dairy cattle class was calculated according to Minson \& McDonald (1987) from liveweight and liveweight gain data:

$\mathrm{I}=\left(1.185+0.00454 \mathrm{~W}-0.0000026 \mathrm{~W}^{2}+0.315 \mathrm{LWG}\right)^{2} \mathrm{x} \mathrm{MR}+\mathrm{MI}$

Equation 1

Where: $\quad I$ = intake $(\mathrm{kg} \mathrm{DM} /$ head/day)

$\mathrm{W}=$ weight in $\mathrm{kg}$ (Appendix A.1, 2)

LWG = liveweight gain in $\mathrm{kg} /$ day (Appendix A.1, 2)

MR = metabolic rate when producing milk (SCA, 1990); 1.1 for cows in milk and 1 for all other classes.

Additional intake for milk production from lactating animals (MI) was included to give a total intake (kg DM/head/day):

$\mathrm{MI}=\mathrm{MP} \times \mathrm{NE} / \mathrm{k}_{l} / \mathrm{q}_{m} / 18.4$ Equation 2

Where: $\quad$ MP $=$ milk production $(\mathrm{kg} / \mathrm{head} /$ day) from LACTO data (2010).

$\mathrm{NE}=3.054 \mathrm{MJ} \mathrm{NE} / \mathrm{kg}$ milk (SCA, 1990)

$\mathrm{k}_{l}=0.60$ efficiency of use of ME for milk production (SCA, 1990)

$\mathrm{q}_{m}=$ metabolizability of the diet. (i.e. ME/GE). Calculated using the equation of Minson \& McDonald (1987),

$\mathrm{q}_{m}=0.00795 \mathrm{DMD}-0.0014$ (where DMD is expressed as a \%). (Appendices A.1, 2 and B.4)

Assuming a gross energy content of DM of $18.4 \mathrm{MJ} / \mathrm{kg}$ (SCA, 1990) the gross energy intake (GEI) of all dairy cattle classes was calculated as the sum of intake (I) multiplied by $18.4 \mathrm{MJ} / \mathrm{kg} \mathrm{DM}$. Intake of 
animals relative to that needed for maintenance (L) was calculated as actual intake divided by maintenance intake (intake of a non-lactating animal with liveweight gain set to zero):

$\mathrm{L}=\mathrm{I} /\left(1.185+0.00454 \mathrm{~W}-0.0000026 \mathrm{~W}^{2}+(0.315 \times 0)\right)^{2}$. Equation 3

Blaxter \& Clapperton's (1965) equation was used to calculate the percentage of GEI that is yielded as methane $(\mathrm{Y})$ :

$\mathrm{Y}=1.3+0.112 \mathrm{DMD}+\mathrm{L}(2.37-0.050 \mathrm{DMD})$ Equation 4

Where: $\quad$ DMD $=$ dry matter digestibility (\%) (Appendices A.1, 2 and B.4)

$\mathrm{L}=$ intake relative to that needed for maintenance.

The total daily production of methane (M), $\left(\mathrm{kg} \mathrm{CH}_{4} /\right.$ head/ day) was calculated as:

$\mathrm{M}=\mathrm{Y} / 100 \mathrm{x} \mathrm{GEI} / \mathrm{F}$

Equation 5

Where: $\quad \mathrm{F}=55.22 \mathrm{MJ} / \mathrm{kg} \mathrm{CH}_{4}$ (Brouwer, 1965).

$\mathrm{GEI}=$ Gross energy intake (MJ/day).

\section{Beef cattle}

Population data for 2010 and the herd structure for commercial and communal beef cattle on a provincial basis were sourced from Statistics South Africa (Stats SA), the Department of Agriculture, Forestry and Fisheries (DAFF) and the Agricultural Research Council (ARC) of South Africa (StatsSA, 2010; DAFF, 2010; J. van der Westhuizen \& H.E. Theron, 2012, Pers. Comm., SA Stud Book, P.O. Box 270, Bloemfontein, 9300, South Africa).

South African beef cattle production systems are mainly extensive and based on veld (i.e. rangeland or natural pastures). Tainton (1981) divided veld in South Africa into three broad types, namely sweetveld, sourveld and mixed veld. The percentage of each veld type in each province was estimated according to a map produced by Tainton (1999). The seasonal variation in veld quality and digestibly was sourced from the literature (Dugmore \& Du Toit, 1988; De Waal, 1990; O’Reagain \& Owen-Smith, 1996).

The commercial beef herd is composed of approximately 70\% medium frame cattle (Bonsmara type), 15\% large frame and 15\% small frame (J. van der Westhuizen \& H.E. Theron, 2012, Pers. Comm., SA Stud Book, P.O. Box 270, Bloemfontein, 9300, South Africa). Liveweights for each frame type were calculated from weight data published by Meissner et al. (1983) and verified with cattle breed societies. The average liveweight per beef cattle age group or class was estimated according to the ratio (above) of medium, large and small frame breed types (70:15:15). Communal cattle liveweights were calculated from the commercial cattle weights with a $20 \%$ reduction, since communal cattle are more Sanga and Zebu types, fed on lowerquality diets and with lower intakes. Liveweight, liveweight gain, feed characteristics and management data used in the algorithms are presented in Appendices B.1 to B.5.

Dry matter intake for each beef cattle class was calculated according to the equation presented by Minson \& McDonald (1987) (Equation 1). Feed intake increases during lactation. It was assumed that the intake of all breeding cows increased by $30 \%$ during the season in which calving occurs and by $10 \%$ in the following season (SCA, 1990) as energy requirement for milk production declines during the second half of lactation.

Additional intake for milk production (MA) was calculated as:

$\mathrm{MA}=(\mathrm{LC} \times \mathrm{FA})+((1-\mathrm{LC}) \times 1)$

Equation 6

Where: $\quad$ LC $=$ proportion of cows $>2$ years lactating

$\mathrm{FA}=$ feed adjustment (1.3 during the season of calving and 1.1 during the following season).

Calving percentage of $62 \%$ for commercial cattle and 35\% for communal cattle (Scholtz et al., 2012) were used to calculate MA. A single calving season was used for commercial cattle and it was assumed that communal cattle would calve throughout the year. As feed dry matter has a gross energy concentration of 18.4 MJ/ kg (SCA, 1990), the DMI was converted to GEI (MJ/ day) by: 
GEI $=$ I x 18.4 Equation 7

The intake of cattle relative to that needed for maintenance (L) was calculated using equation 3 . The percentage of GEI that is yielded as methane (Y) was calculated according to equation 4. Kurihara et al. (1999) developed an equation to calculate the total daily methane production (M), (kg/CH$/$ head/day) for animals grazing tropical pastures. This equation (equation 8) was used to calculate the methane production from commercial and communal cattle:

$\mathrm{M}=(34.9 \times \mathrm{I}-30.8) / 1000$. Equation 8

Where: $\quad \mathrm{M}=$ methane emissions $\left(\mathrm{kg} / \mathrm{CH}_{4} / \mathrm{head} /\right.$ day $)$

$\mathrm{I}=$ intake.

\section{Feedlot cattle}

The 2010 provincial data on cattle in feedlots were sourced from the South African Feedlot Association (SAFA, 2012). The feedlot enteric methane emission (Y), ( $\mathrm{MJ} \mathrm{CH}_{4} /$ head/day) calculations are based on intake of specific diet components using an equation developed by Moe \& Tyrrell (1979):

$\mathrm{Y}=3.406+0.510 \mathrm{SR}+1.736 \mathrm{H}+2.648 \mathrm{C}$

Equation 9

Where: $\quad \mathrm{SR}=$ intake of soluble residue $(\mathrm{kg} /$ day $)$

$\mathrm{H}=$ intake of hemicellulose $(\mathrm{kg} /$ day)

$\mathrm{C}=$ intake of cellulose ( $\mathrm{kg} /$ day).

Soluble residue intake, hemicellulose intake and cellulose intake were calculated from feedlot diet analysis (ANIR, 2010) and average DM intake taken as $8.5 \mathrm{~kg}$ DM/day (SAFA, 2012 and industry experts) (Appendices C.1 to C.3). Total daily methane production (M), ( $\mathrm{kg} \mathrm{CH}_{4} /$ head/day) was calculated as:

$\mathrm{M}=\mathrm{Y} / \mathrm{F}$. Equation 10

Where: $\quad \mathrm{F}=55.22 \mathrm{MJ} / \mathrm{kg} \mathrm{CH}$ (Brouwer, 1965).

Feedlot calculations were based on the assumption that an animal will stay in the feedlot for approximately 110 days (three cycles per year).

\section{Manure management}

Methane production from manure management of dairy, beef, and feedlot cattle were calculated based on the approach of the IPCC (2006) using a combination of default IPCC and country-specific input values. The authors of the ANIR (2010) stated that high temperatures, high solar radiation and low humidity environments would dry manure rapidly and that methane production was likely to be negligible in manure of range-kept livestock. Gonzalez-Avalos \& Ruiz-Suarez (2001) recorded a negligible amount of methane emitted from manure of cattle kept under conditions similar to those in South Africa and Australia. The Australian methodology calculated the manure emissions factor (MEF) of range-kept cattle in environments with an average temperature of $21^{\circ} \mathrm{C}$ as $1.4 \times 10^{-5} \mathrm{~kg} \mathrm{CH}_{4} / \mathrm{kg} \mathrm{DM}$ manure, based on the results of GonzalezAvalos \& Ruiz-Suarez (2001).

\section{Dairy cattle}

Methane emissions from manure originate from the organic fraction of the manure (volatile solids). Volatile solids (VS), (kg/head/day) for South African dairy cattle were calculated according to ANIR (2010) as:

$\mathrm{VS}=\mathrm{I} \times(1-\mathrm{DMD}) \times(1-\mathrm{A})$ Equation 11

Where: $\quad I=$ dry matter intake calculated as described above DMD = dry matter digestibility expressed as a fraction (Appendices: A.1 and A.2) $\mathrm{A}=$ ash content of manure expressed as a fraction (assumed to be $8 \%$ of faecal DM). 
The percentage of manure managed in different manure management systems in South Africa and the manure methane conversion factors (ANIR, 2010) for these systems are reported in Appendix A.3. Methane production from manure $(\mathrm{M})(\mathrm{kg} / \mathrm{head} /$ day) was calculated as:

$\mathrm{M}=\mathrm{VS} \times \mathrm{B}_{0} \times \mathrm{MCF} \times \mathrm{p}$

Equation 12

Where: $\quad \mathrm{B}_{0}=$ emissions potential $\left(0.24 \mathrm{~m}^{3} \mathrm{CH}_{4} / \mathrm{kg}\right.$ VS) ( IPCC, 2006)

$\mathrm{MCF}=$ integrated methane conversion factor - based on the proportion of the different manure management systems and the MCF for warm regions (Appendix A)

$p=$ density of methane $\left(0.662 \mathrm{~kg} / \mathrm{m}^{3}\right)$.

The integrated MCF for lactating dairy cattle in TMR-based production systems was calculated as $10.07 \%$ and $1 \%$ for all other classes of dairy cattle. In pasture-based production systems the integrated MCF for lactating cattle was calculated as $3.64 \%$ and $1 \%$ for all other classes of cattle.

\section{Beef cattle}

South African beef production systems are mainly extensive and manure is deposited directly onto pastures and not actively managed. Methane emissions from manure (M), (kg/head/day) of beef cattle were calculated according to the ANIR (2010) as:

$\mathrm{M}=\mathrm{I} \times(1-\mathrm{DMD}) \mathrm{x}$ MEF.

Equation 13

Where: $\quad I=$ intake as calculated under enteric emissions (Equation 1)

$\mathrm{DMD}=$ dry matter digestibility across seasons (Appendix B.4)

$\mathrm{MEF}=$ emissions factor $\left(\mathrm{kg} \mathrm{CH}_{4} / \mathrm{kg}\right.$ DM manure). The factor of $1.4 \times 10^{-5}$ based on the work of Gonzalez-Avalos \& Ruiz-Suarez (2001) was used.

\section{Feedlot cattle}

The high stocking density of animals in feedlots results in a build-up of manure, which may lead to the production of methane, especially when the manure is wet. The method of manure management at a feedlot influences the amount of methane that is emitted from it. South African feedlots manage manure mainly by dry packing, which results in only a small fraction of potential methane emissions being generated (IPCC, 1997). The Australian national inventory (ANIR, 2010) reported default values for drylot methane conversion factors (MCF) of $1.5 \%$ based on the IPCC (1997). The volatile solid production for feedlot cattle was estimated based on data developed under the enteric methane emission calculations reported earlier.

The volatile solid production was calculated by equation 11 assuming a DMD of $80 \%$ for feedlot diets. The daily methane production from feedlot manure was then calculated using equation 12, assuming an emissions potential $\left(\mathrm{B}_{0}\right)$ of $0.17 \mathrm{~m}^{3} \mathrm{CH}_{4} / \mathrm{kg}$ VS (IPCC, 2006) and a MCF of $1.5 \%$ as stated above.

\section{Nitrous oxide emissions \\ Dairy cattle}

The methodology for calculating nitrous oxide $\left(\mathrm{N}_{2} \mathrm{O}\right)$ emissions from dairy cattle is based on the calculation of crude protein input (CPI) and nitrogen storage (NR) based on the ANIR (2010).

The crude protein intake of dairy cattle was calculated as:

$\mathrm{CPI}=\mathrm{I} \times \mathrm{CP}$

Equation 14

Where: $\quad$ I $=$ dry matter intake $(\mathrm{kg} /$ day) calculated under enteric methane emission calculation (Equation 1)

$\mathrm{CP}=$ crude protein of feed intake expressed as a fraction (Appendices A.1 and A.2).

Nitrogen excreted in faeces $(\mathrm{F})(\mathrm{kg} / \mathrm{head} /$ day) was calculated from the equation developed in Australia by the SCA (1990) and Freer et al. (1997) as:

$F=\{0.3($ CPI x $(1-[(D M D+10 / 100]))+0.105($ ME x I x 0.008) $+(0.0152 \times$ I $)\} / 6.25 \quad \ldots .$. Equation 15

Where: $\quad$ DMD $=$ dry matter digestibility expressed as a \% (Appendices A.1 and A.2) 
$\mathrm{ME}=$ metabolizable energy $(\mathrm{MJ} / \mathrm{kg} \mathrm{DM})$ calculated as: 0.1604DMD - 1.037 (Minson \& McDonald, 1987).

$\mathrm{I}=$ dry matter intake (kg/day) (Equation 1$)$

$1 / 6.25$ = factor of converting CP into nitrogen.

Nitrogen retention (NR) was calculated as the amount of nitrogen in milk and body tissue and according to the ANIR (2010) as:

$\mathrm{NR}=\{(0.032 \times \mathrm{MP})+\{0.212-0.008(\mathrm{~L}-2)-[(0.140-0.008(\mathrm{~L}-2) /(1+\exp (-6(\mathrm{Z}-0.4)))\}\} \times(\mathrm{LWG} \times$

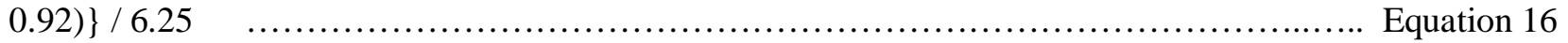

Where: $\quad$ MP = milk production in $\mathrm{kg} /$ day (LACTO data, 2010)

$\mathrm{L}=$ relative intake as calculated under the enteric methane section (Equation 3)

$\mathrm{Z}$ = relative size (liveweight/ standard reference weight (Appendix A.5))

LWG = liveweight gain (Appendices A.1 and A.2).

Nitrogen excreted through the urine (U, kg/head/day) was calculated according to the ANIR (2010) by subtracting NR, F and dermal protein loss from nitrogen intake:

$\left.\mathrm{U}=(\mathrm{CPI} / 6.25)-\mathrm{NR}-\mathrm{F}-\left[\left(1.1 \times 10^{-4} \mathrm{x} \mathrm{W}^{0.75}\right) / 6.25\right)\right]$ Equation 17

The total annual faecal (AF), (Gg) and urinary (AU), (Gg) nitrogen excreted per head was calculated as:

$\mathrm{AF}=(365 \times \mathrm{N} \times \mathrm{F}) \times 10^{-6}$ Equation 18

$\mathrm{AU}=(365 \times \mathrm{N} \times \mathrm{U}) \times 10^{-6}$ Equation 19

The total emissions of nitrous oxide from the different manure management systems were then calculated according to the ANIR (2010) as:

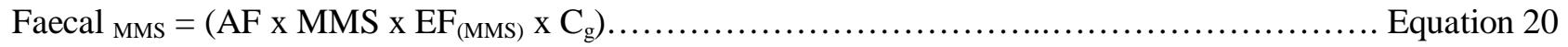

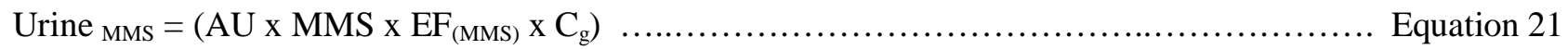

Where: $\quad$ MMS = the fraction of manure managed in different manure management systems (Appendix A.3)

$\mathrm{EF}=$ emission factor $\left(\mathrm{N}_{2} \mathrm{O}-\mathrm{N} \mathrm{kg} / \mathrm{N}\right.$ excreted) for the different MMS (Appendix A.4)

$\mathrm{Cg}=44 / 28$ to convert elemental mass of $\mathrm{N}_{2} \mathrm{O}$ to molecular mass.

The total direct nitrous oxide emissions from dairy cattle were then calculated as the sum of faecal and urine MMS.

\section{Beef cattle}

Nitrous oxide emissions originating from beef cattle manure deposited on rangelands are not reported under livestock emissions (IPCC, 2006). The emission factor $\left(\mathrm{kg} \mathrm{N}_{2} \mathrm{O}-\mathrm{N} / \mathrm{kg} \mathrm{N}\right.$ excreted) is reported to be 0 (IPCC, 2006). According to the IPCC (2006), nitrous oxide emissions from manure deposited on pasture or veld is reported under the managed agricultural soils sections in the national inventory report format and not under livestock emissions. Nitrous oxide emitted from soil through the metabolism of urine and faeces deposited directly on pastures or veld was calculated according to the ANIR (2009).

\section{Feedlot cattle}

The methodology for calculating the nitrogen excretion of feedlot cattle is based on the ANIR (2009) and is similar to the $\mathrm{N}_{2} \mathrm{O}$ calculations from dairy cattle. The crude protein intake of feedlot cattle (CPI), (kg/head/day) was calculated as: 
Where: $\quad$ NI $=$ nitrogen intake $(\mathrm{kg} /$ day $)$

6.25 = factor for converting nitrogen into crude protein

Faecal nitrogen excretion (F), (kg/head/day) was calculated based on equations from SCA (1990) and Freer et al. (1997) as:

$\mathrm{F}=\{0.3(\mathrm{CPI} \times(1-[(\mathrm{DMD}+10 / 100]))+0.105(\mathrm{ME} \times \mathrm{I} \times 0.008)+(0.0152 \times \mathrm{I})\} / 6.25$

Equation 23

Where: $\quad$ DMD $=$ dry matter digestibility expressed as a $\%(80 \%)$

$\mathrm{ME}=$ metabolizable energy (MJ/kg DM) calculated as: 0.1604DMD - 1.037 (Minson \&

McDonald, 1987)

$\mathrm{I}=$ dry matter intake (kg/day) $(8.5 \mathrm{~kg} \mathrm{DM} / \mathrm{head} /$ day $)$

$1 / 6.25$ = factor of converting CP into nitrogen.

The amount of nitrogen retained in the body (NR), the nitrogen excreted in urine (U), and the total nitrous oxide emissions from feedlot cattle were calculated using equations 16 to 21 above.

\section{Results and Discussion}

The total methane emissions produced from South African livestock species in 2010 were estimated at 1328 Gg/year (Du Toit et al., 2012). Methane emissions from the South African cattle industries have been calculated as $964 \mathrm{Gg}$ or $72.6 \%$ of the total livestock methane emissions during the same period. The contributions of dairy cattle, beef cattle on veld and feedlot cattle to the total cattle methane emissions were $13.5 \%, 83.3 \%$ and $3.2 \%$, respectively. Otter (2010) reported the proportional contribution of dairy cattle as $14.3 \%$, beef cattle on veld as $84.6 \%$ and feedlot cattle as $1.11 \%$ in South Africa. In comparison, livestock in Brazil produced a total of $9937 \mathrm{Gg}$ during 1995 with beef cattle producing $80.9 \%$ and dairy cattle $13.6 \%$ of the total livestock methane emissions (Lima et al., 2002). Indian livestock produced a total of $9093 \mathrm{Gg}$ of methane in 2006 with beef cattle producing only 35.9\%, buffalo $7.08 \%$ and dairy cattle $19.9 \%$ of the total livestock methane emissions (Swammy \& Bhattacharya, 2006).

The direct GHG emissions from all cattle (dairy, commercial beef, communal beef and feedlot cattle) in South Africa are presented in Table 2 on a provincial basis. The Eastern Cape province has the highest methane emissions profile originating from cattle followed by KwaZulu-Natal, Free State and the North West, reflecting to a large extent the population numbers. Otter (2010) reported the total enteric methane emission of all cattle classes as $1050 \mathrm{Gg}$ and the methane emitted from manure as $97.1 \mathrm{Gg}$ based on 2004 population data using the IPCC Tier 2 approach. The enteric methane emission figures calculated for 2010 correspond well with the figures reported by Otter (2010) but there is large variation in the methane

Table 2 Provincial and total cattle methane and nitrous oxide emissions, 2010

\begin{tabular}{lccc}
\hline & Enteric methane (Gg) & Manure methane (Gg) & Nitrous oxide (Gg)* $^{*}$ \\
\hline Western Cape & 62.5 & 2.44 & 0.13 \\
Eastern Cape & 210 & 1.00 & 0.01 \\
Northern Cape & 49.9 & 0.12 & 0.01 \\
KwaZulu-Natal & 182 & 0.80 & 0.02 \\
Free State & 152 & 1.60 & 0.12 \\
North West & 115 & 0.87 & 0.08 \\
Gauteng & 29.2 & 0.52 & 0.11 \\
Mpumalanga & 92.8 & 0.51 & 0.04 \\
Limpopo & 63.5 & 0.12 & 0.02 \\
Total & 956 & 7.98 & 0.54
\end{tabular}

* $\mathrm{N}_{2} \mathrm{O}$ emissions originating from fertilized pastures and faecal matter voided at pasture or veld is not included. Gg: Giga gram. 
emissions originating from manure. These differences may be owing to the methodologies employed to calculate volatile solid excretion and the manure management systems allocated to different types of cattle. Western Cape, Free State, Gauteng and North West have the highest nitrous oxide emissions originating from cattle. This is owing to the number of dairy and feedlot cattle in these provinces as well as differences in management systems among them.

The calculated methane emission factors (MEF) for South African dairy cattle are presented in Tables 3 and 4. Production systems based on concentrate feeds (TMR-based) have higher emission factors than pasture-based production systems except for the dry cow category. This is expected, owing to the higher digestibilities of concentrate-based diets as well as the higher intakes achieved by animals receiving concentrate diets. Lactating animals have the highest MEF, owing to increased energy requirements for production and differences in manure management systems compared with other dairy cattle classes.

Table 3 Direct methane and nitrous oxide emission factors for TMR-based dairy cattle, 2010

\begin{tabular}{lcccc}
\hline Animal class & Weight (kg) & $\begin{array}{c}\mathbf{M E F}_{\text {enteric }} \\
(\mathbf{k g} / \mathbf{h} / \mathbf{y e a r})^{*}\end{array}$ & $\begin{array}{c}\mathbf{M E F} \text { manure } \\
(\mathbf{k g} / \mathbf{h} / \mathbf{y e a r})^{*}\end{array}$ & $\begin{array}{c}\mathbf{N}_{2} \mathbf{O} \\
(\mathbf{k g} / \mathbf{h} / \mathbf{y e a r})^{*}\end{array}$ \\
\hline Lactating cows & 590 & 132 & 14.8 & 0.855 \\
Lactating heifers & 503 & 127 & 14.7 & 0.836 \\
Dry cows & 590 & 80.4 & 1.47 & - \\
Pregnant heifers & 394 & 67.7 & 1.24 & - \\
Heifers > 1 year & 322 & 62.6 & 1.19 & - \\
Heifers 6 - 12 months & 172 & 42.1 & 0.75 & - \\
Heifers 2 - 6 months & 55 & 22.5 & 0.37 & - \\
Calves & 35 & 21.5 & 0.21 & - \\
& & & & \\
\hline
\end{tabular}

MEF: methane emissions factor. * kg/head/year.

Table 4 Direct methane and nitrous oxide emission factors for pasture-based dairy cattle, 2010

\begin{tabular}{|c|c|c|c|c|}
\hline Animal class & Weight (kg) & $\begin{array}{l}\text { MEF }_{\text {enteric }} \\
\text { (kg/h/year)* }^{*}\end{array}$ & $\begin{array}{l}\text { MEF }_{\text {manure }} \\
\text { (kg/h/year)* }^{*}\end{array}$ & $\begin{array}{c}\mathrm{N}_{2} \mathrm{O} \\
\text { (kg/h/year)* }\end{array}$ \\
\hline Lactating cows & 540 & 127 & 4.98 & 0.029 \\
\hline Lactating heifers & 438 & 116 & 4.80 & 0.027 \\
\hline Dry cows & 540 & 83.4 & 1.11 & - \\
\hline Pregnant heifers & 333 & 61.8 & 0.88 & - \\
\hline Heifers $>1$ year & 254 & 52.6 & 0.78 & - \\
\hline Heifers 6 - 12 months & 142 & 37.1 & 0.58 & - \\
\hline Heifers 2 - 6 months & 54 & 24.5 & 0.40 & - \\
\hline Calves & 36 & 20.0 & 0.32 & - \\
\hline
\end{tabular}

MEF: methane emissions factor; * kg/head/year.

The calculated enteric and manure methane emission factors for South African dairy cattle are higher than dairy cattle emissions factors in other developing countries such as Brazil, with $62 \mathrm{~kg} / \mathrm{head} /$ year and 3 $\mathrm{kg} /$ head/year, respectively, and India, with $35.5 \mathrm{~kg} / \mathrm{head} /$ year and $3.65 \mathrm{~kg} / \mathrm{head} /$ year, respectively, as reported by Lima et al. (2002) and Chhabra et al. (2012). The IPCC (2006) reported enteric and manure methane emission default factors for Africa of $46 \mathrm{~kg} / \mathrm{head} /$ year and $1 \mathrm{~kg} / \mathrm{head} / \mathrm{year}$, respectively. These figures are considerably lower than the national dairy herd average across all age groups of $76.4 \mathrm{~kg} / \mathrm{head} /$ year and 71.8 $\mathrm{kg} / \mathrm{head} /$ year for enteric emissions and $4.9 \mathrm{~kg} / \mathrm{head} / \mathrm{year}$ and $1.93 \mathrm{~kg} / \mathrm{head} /$ year for manure emissions for 
TMR- and pasture-based production systems, respectively. These values are reported in Tables 3 and 4. South African calculated methane emission factors are more comparable with emission factors from developed countries for enteric and manure emissions such as the United Kingdom (109 and 28 kg/head/year), Australia (115 and $8.87 \mathrm{~kg} /$ head/year) and New Zealand (79.3 and $3.29 \mathrm{~kg} / \mathrm{head} /$ year) as reported by ANIR (2010) and the New Zealand GHG Inventory (2010).

Table 5 reports total methane and nitrous oxide emissions for the dairy cattle on a provincial basis during 2010. The South African dairy industry consists predominantly of concentrate-based (TMR) production systems except for Eastern Cape and KwaZulu-Natal, which use mainly pasture-based production systems. Western Cape, Eastern Cape and KwaZulu-Natal are responsible for approximately $67.2 \%$ of the dairy industry's direct $\mathrm{CH}_{4}$ emissions (Table 5). Approximately $81 \%$ of the total direct $\mathrm{N}_{2} \mathrm{O}$ emissions of $0.31 \mathrm{Gg}$ are produced in Western Cape, Free State and North West (Table 5). Nitrous oxide emitted from soil through the metabolism of faecal matter deposited directly on pastures by dairy cattle was estimated at 0.88 Gg on a national scale.

Table 5 Provincial and total methane (Gg) and nitrous oxide (Gg) emissions of dairy cattle based on 2010 data

\begin{tabular}{lcccc}
\hline Province & Population $^{\mathbf{a}}$ & $\begin{array}{c}\text { Enteric methane } \\
(\mathbf{G g})\end{array}$ & $\begin{array}{c}\text { Manure methane } \\
(\mathbf{G g})\end{array}$ & $\begin{array}{c}\text { Nitrous oxide* } \\
(\mathbf{G g})\end{array}$ \\
\hline Western Cape & 338351 & 29.7 & 2.43 & 0.13 \\
Eastern Cape & 366197 & 30.3 & 0.96 & 0.005 \\
Northern cape & 13923 & 1.22 & 0.10 & 0.005 \\
KwaZulu-Natal & 282217 & 23.4 & 0.74 & 0.004 \\
Free State & 208624 & 18.3 & 1.50 & 0.08 \\
North West & 107627 & 9.44 & 0.77 & 0.041 \\
Gauteng & 46410 & 4.07 & 0.33 & 0.018 \\
Mpumalanga & 63648 & 5.58 & 0.46 & 0.024 \\
Limpopo & 12597 & 1.10 & 0.09 & 0.005 \\
Total & 1439594 & 123 & 7.38 & 0.31 \\
\end{tabular}

${ }^{2}$ LACTO data (2010); Gg: Giga gram.

* $\mathrm{N}_{2} \mathrm{O}$ emissions originating from fertilized pastures and faecal matter voided at pasture or veld is not included.

The South African beef industry is characterised by two distinct sectors, the commercial beef sector, including feedlot production systems, and emerging and communal (subsistence) production systems. These systems differ in breed type, feed availability, feed quality, level of production and production efficiency.

Table 6 Methane emissions factors for commercial beef cattle

\begin{tabular}{lccc}
\hline Animal class & $\begin{array}{c}\text { Weight } \\
(\mathbf{k g})\end{array}$ & $\begin{array}{c}\text { MEF } \\
(\mathbf{k g} / \mathbf{h} / \mathbf{y e a r})\end{array}$ & $\begin{array}{c}\text { MEF } \\
\mathbf{( k g} / \mathbf{h} / \mathbf{y e a r})\end{array}$ \\
\hline Bulls & & & \\
Cows & 733 & 113 & 0.022 \\
Heifers & 475 & 92.6 & 0.018 \\
Oxen & 365 & 75.9 & 0.016 \\
Young oxen & 430 & 89.4 & 0.018 \\
Calves & 193 & 51.6 & 0.012 \\
& 190 & 51.6 & 0.012 \\
\hline
\end{tabular}

MEF: methane emissions factor; kg/h/year: kg/head/year. 
The MEFs for commercial and communal beef production systems are reported in Tables 6 and 7, respectively. The emissions factors were calculated on a Tier 2 level (IPCC, 2006). Nitrous oxide emissions are not allocated to beef cattle, as the emission factor for manure deposited on veld $\left(\mathrm{kg} \mathrm{N}_{2} \mathrm{O}-\mathrm{N} / \mathrm{kg} \mathrm{N}\right.$ excreted) is 0 and $\mathrm{N}_{2} \mathrm{O}$ emission from manure deposited on veld and pasture is reported under the managed agricultural soils section in the national inventory report format (IPCC, 2006). Penttilä et al. (2013) reported that dung beetles could potentially increase GHG emissions from livestock faeces voided on rangeland or veld, mainly due to increased $\mathrm{N}_{2} \mathrm{O}$ emissions. The possible effect of dung beetles is noted but not included in the present inventory due to insufficient data under South African conditions.

Table 7 Methane emissions factors for communal beef cattle

\begin{tabular}{lccc}
\hline Animal class & $\begin{array}{c}\text { Weight } \\
(\mathbf{k g})\end{array}$ & $\begin{array}{c}\mathbf{M E F}_{\text {entric }} \\
(\mathbf{k g} / \mathbf{h} / \mathbf{y e a r})\end{array}$ & $\begin{array}{c}\mathbf{M E F}_{\text {manure }} \\
\mathbf{( k g} / \mathbf{h} / \mathbf{y e a r})\end{array}$ \\
\hline Bulls & 462 & 83.8 & 0.017 \\
Cows & 360 & 73.1 & 0.015 \\
Heifers & 292 & 62.5 & 0.013 \\
Oxen & 344 & 72.6 & 0.015 \\
Young oxen & 154 & 41.6 & 0.010 \\
Calves & 152 & 40.9 & 0.010 \\
\hline
\end{tabular}

MEF: methane emissions factor; kg/h/year: kg/head/year.

Commercial cattle are heavier and have higher intakes of better quality diets than emerging sector and communal cattle. This results in higher MEF factors for commercial cattle. Although commercial cattle have higher MEF per head, they are more productive, and the methane emissions per kg product or per hectare should be lower than that of communal cattle.

The extensive beef cattle sector is the largest contributor to the cattle sector's GHG emissions, contributing $54.7 \%$ and $28.6 \%$ for commercial and emerging/communal cattle, respectively. The Eastern Cape has the highest beef cattle methane emissions in both commercial and emerging/communal production systems, followed by KwaZulu-Natal, Free State and the North West (Table 8). Although nitrous oxide emissions from faecal matter voided on veld or pastures are not reported under livestock emissions according to the IPCC (2006) good practice guidelines, these emissions are reported to provide a more complete scenario of emissions associated with extensive beef production systems in South Africa. Nitrogen in faecal matter is primarily organic and must first be mineralized before it becomes a source of $\mathrm{N}_{2} \mathrm{O}$. The mineralization process occurs at significant rates in higher rainfall regions. However, the decay of faeces in drier areas is much slower, with faeces remaining largely intact for months to years (ANIR, 2009). The $\mathrm{N}_{2} \mathrm{O}$ emissions from faeces and urine voided on grazing was estimated at $1.3 \mathrm{Gg} \mathrm{N} \mathrm{N}_{2} \mathrm{O}$ /year for commercial cattle and $0.61 \mathrm{Gg} \mathrm{N} \mathrm{N}_{2} \mathrm{O}$ /year for communal cattle on a national scale using emissions factors of 0.005 and $0.004 \mathrm{Gg}$ $\mathrm{N}_{2} \mathrm{O}-\mathrm{N} / \mathrm{Gg} \mathrm{N}$ for faeces and urine, respectively, according to the ANIR (2009).

Feedlot cattle represent a small proportion of national cattle GHG emissions. This is owing to the relative small size of the industry and the duration the animals spend in a feedlot (approximately 110 days per cycle). The emission factors (kg/head/year) for feedlot cattle are presented in Table 9 . Feedlot cattle have a relative high $\mathrm{N}_{2} \mathrm{O}$ emission factor in relation to their manure methane emissions factor compared to dairy cattle.

Gauteng represents approximately $42 \%$ of the total feedlot emissions, followed by Free State with 17.6\% and North West with 17.4\% (Table 9). The methane emissions from manure in the Western Cape and Eastern Cape are negligible and, owing to rounding of figures to two decimals, these figures are presented as 0.00 in Table 10.

Dry matter intake calculated for all cattle categories falls within the range reported by the IPCC (2006) of $1 \%-3 \%$ of body weight (BW). Dairy cattle intake figures ranged from $1.5 \%$ to $4.8 \%$ of BW, commercial cattle intake from $1.3 \%$ to $2.6 \%$ of BW, communal cattle intake from $1.6 \%$ to $2.7 \%$ of $\mathrm{BW}$ and feedlot cattle 
intake was estimated at 2.5\% of BW. Dairy cattle heifers 2 - 6 months and calves had a higher intake of $4.25 \%$ and $4.8 \%$ of BW, respectively. These intake figures correspond with intakes predicted for cattle of similar weight classes and production status in international sources (ANIR, 2010).

Table 8 Provincial and total methane emissions of extensive beef cattle based on 2010 data

\begin{tabular}{lcccccc}
\hline Province & Population & $\begin{array}{c}\text { Commercial cattle } \\
\text { Enteric } \\
\text { methane } \\
\text { (Gg) }\end{array}$ & $\begin{array}{c}\text { Manure } \\
\text { methane } \\
\text { (Gg) }\end{array}$ & Population & $\begin{array}{c}\text { Energing/Communal cattle } \\
\text { Enteric } \\
\text { methane } \\
\text { (Gg) }\end{array}$ & $\begin{array}{c}\text { Manure } \\
\text { methane } \\
\text { (Gg) }\end{array}$ \\
\hline $\begin{array}{l}\text { Western } \\
\text { Cape }\end{array}$ & 341892 & 21.5 & 0.0043 & 232108 & 11.2 & 0.0024 \\
$\begin{array}{l}\text { Eastern Cape } \\
\text { Northern }\end{array}$ & 1873852 & 118 & 0.024 & 1272148 & 61.3 & 0.013 \\
$\begin{array}{l}\text { Cape } \\
\text { KwaZulu- }\end{array}$ & 603154 & 37.9 & 0.0074 & 207846 & 10.0 & 0.0021 \\
Natal & 1644534 & 103 & 0.021 & 1116466 & 53.8 & 0.012 \\
Free State & 1341359 & 84.2 & 0.017 & 910641 & 43.9 & 0.009 \\
North West & 1049500 & 65.9 & 0.0132 & 712500 & 34.4 & 0.0073 \\
Gauteng & 14268 & 0.90 & 0.0002 & 244732 & 11.8 & 0.0026 \\
Mpumalanga & 887489 & 55.7 & 0.0012 & 602511 & 29.1 & 0.0064 \\
Limpopo & 638515 & 40.1 & 0.008 & 433485 & 20.9 & 0.0045 \\
Total & 8394563 & 527 & 0.096 & 5732437 & 276 & 0.059 \\
\hline
\end{tabular}

Gg: Giga gram.

Table 9 Direct methane and nitrous oxide emission factors for South African feedlot cattle

\begin{tabular}{lcccc}
\hline Animal Class & $\begin{array}{c}\text { Ave Weight } \\
(\mathbf{k g})\end{array}$ & $\begin{array}{c}\mathbf{M E F}_{\text {enteric }} \\
\mathbf{( k g / h / y e a r )}\end{array}$ & $\begin{array}{c}\mathbf{M E F}_{\text {manure }} \\
(\mathbf{k g} / \mathbf{h} / \text { year })\end{array}$ & $\begin{array}{c}\mathbf{N}_{2} \mathbf{O}^{*} \\
(\mathbf{k g} / \mathbf{h} / \mathbf{y e a r})\end{array}$ \\
\hline Growing animal & 335 & 58.9 & 0.87 & 0.457
\end{tabular}

MEF: methane emissions factor; $\mathrm{kg} / \mathrm{h} /$ year: $\mathrm{kg} / \mathrm{head} /$ year.

${ }^{*} \mathrm{~N}_{2} \mathrm{O}$ emissions originating from fertilized pastures and faecal matter voided at pasture or veld is not included.

The averaged calculated emissions factors for all cattle have been compared to the IPCC (2006) default values for Africa (Table 11).

The calculated dairy cattle emission factors are considerably higher than the IPCC (2006) default emissions factors for Africa. The IPCC based their emission factors for commercial dairy cattle on animals grazing with low production (average milk production of $475 \mathrm{~kg} /$ head/year). The milk production of South African commercial dairy cattle ranges from approximately 3000 to $5000 \mathrm{~kg} / \mathrm{head} /$ year (LACTO data, 2010). The emissions factors calculated for lactating dairy cattle are more comparable with the IPCC default values for North America (128 kg/head/year), Western Europe (117 kg/head/year) and Oceania (90 kg/head/year) (IPCC, 2006). The IPCC does not report on feedlot emission factors for Africa, but the calculated emission factors are in line with feedlot values reported for North America (Table 11). The calculated enteric emission factors of veld/extensive beef cattle range from $51.6 \mathrm{~kg} / \mathrm{head} /$ year to 113 for commercial beef cattle and 40.9 - $83.8 \mathrm{~kg} / \mathrm{head} /$ year for emerging/communal beef cattle with a herd average of $79 \mathrm{~kg} / \mathrm{head} / \mathrm{year}$ and 62.4 
$\mathrm{kg} / \mathrm{head} /$ year, respectively, which is higher than IPCC default values for Africa. These values correspond well with those for range kept beef cattle in Australia of $72 \mathrm{~kg} / \mathrm{head} /$ year as reported by the ANIR (2010). The differences in the calculated emission factors and the IPCC default values are mainly because of variations in liveweight and animal productivity used in the calculations. The IPCC calculated emission factors for Africa based on smaller, less productive cattle fed on low-quality diets, which are not representative of South African production systems.

Table 10 Provincial and total GHG emissions of South African feedlot cattle based on 2010 data

\begin{tabular}{lcccc}
\hline Province & Population & $\begin{array}{c}\text { Enteric methane } \\
\text { (Gg) }\end{array}$ & $\begin{array}{c}\text { Manure methane } \\
\text { (Gg) }\end{array}$ & $\begin{array}{c}\text { Nitrous oxide* } \\
\text { (Gg) }\end{array}$ \\
\hline Western Cape & 3000 & 0.18 & $0.00^{\#}$ & 0.0014 \\
Eastern Cape & 5000 & 0.29 & $0.00^{\#}$ & 0.0023 \\
Northern Cape & 13000 & 0.77 & 0.01 & 0.0059 \\
KwaZulu-Natal & 33000 & 1.94 & 0.03 & 0.0151 \\
Free State & 89000 & 5.24 & 0.08 & 0.0407 \\
Mpumalanga & 41000 & 2.41 & 0.04 & 0.0187 \\
Limpopo & 23000 & 1.35 & 0.02 & 0.0105 \\
Gauteng & 211000 & 12.4 & 0.18 & 0.0964 \\
North West & 88000 & 5.18 & 0.08 & 0.0402 \\
Total & 506000 & 29.8 & 0.44 & 0.231
\end{tabular}

" Values too small to include; Gg: Giga gram.

*Values exclude $\mathrm{N}_{2} \mathrm{O}$ emissions originating from fertilised pastures and faecal matter voided at pasture or veld.

Table 11 Average calculated enteric methane emissions factors compared to IPCC default values for Africa (kg/head/year)

\begin{tabular}{llcc}
\hline & & South Africa & IPCC (2006) \\
\hline Dairy cattle & & & 46 \\
& TMR: lactating animals & 130 & 46 \\
& TMR: herd average & 76.4 & 46 \\
& Pasture: lactating animals & 122 & 46 \\
\hline Beef cattle & Pasture: herd average & 71.8 & 31 \\
& Commercial & & 31 \\
& Communal & 79 & $53^{*}$ \\
\hline
\end{tabular}

\footnotetext{
*Feedlot IPCC EF sourced from North American category.

Dairy herd average excludes calve category (35 kg liveweight).
}

The methane emission factors calculated for South African cattle are compared to other developing countries in Table 12. South African cattle emitted more methane annually than Brazilian and Indian cattle (Table 12). The dairy cattle emissions reported in Table 12 are for lactating animals only. The estimated enteric emission factors for South African cattle are higher across all cattle types compared with other developing countries, Brazil and India, which have smaller animals fed on lower-quality diets.

McGinn et al. (2007) and Loh et al. (2008) reported the enteric emission of feedlot cattle of Canada and Australia as $78.1 \mathrm{~kg} / \mathrm{head} /$ year and $60.6 \mathrm{~kg} / \mathrm{head} /$ year, respectively. Hegarty et al. (2007) reported the 
feedlot enteric methane emissions under Australian conditions as ranging from $51.8 \mathrm{~kg} / \mathrm{head} /$ year to 69.4 $\mathrm{kg} / \mathrm{head} /$ year. The calculated emission factor from South African feedlot cattle of $58.9 \mathrm{~kg} / \mathrm{head} /$ year is in line with these values. Canadian feedlot cattle are mainly Bos taurus-type cattle. South African feedlots contain a large percentage of Bos indicus-type cattle, which are well adapted to local conditions and should have lower MEF than Bos taurus cattle owing to lower intakes. Kurihara et al. (1999) measured emissions from Bos indicus cattle under feedlot conditions and fed high grain diets as $48.9 \mathrm{~kg} / \mathrm{head} / \mathrm{year}$.

Table 12 Enteric methane emission factors for South African, Brazilian and Indian cattle

\begin{tabular}{llcccc}
\hline & & \multicolumn{2}{c}{ South Africa } & \multirow{2}{*}{ Brazil $^{1}$} & \multirow{2}{*}{ India $^{2}$} \\
\cline { 3 - 4 } & & Commercial & Communal & & \\
\hline \multirow{2}{*}{$\begin{array}{l}\text { Dairy } \\
\text { cattle }\end{array}$} & LW (kg) & $438-590$ & - & $400-414$ & $175-300$ \\
& DMD (\%) & 76 & - & 55 & $55-62.5$ \\
& Milk production (kg/head/day) & 10.5 & - & $1.08-3.3$ & $1.7-5.7$ \\
& Enteric methane emission factor & $116-132$ & - & $59-65$ & $28-43$ \\
\hline \multirow{2}{*}{ Beef } & (kg/head/year) & 733 & 462 & 450 & \\
cattle & LW (kg):males & 475 & 360 & $280-400$ & $175-300$ \\
& LW (kg):females & 249 & 200 & 230 & 160 \\
& LW (kg):young cattle & $55.8^{*}$ & 55.8 & $50-56$ & $55-62.5$ \\
& DMD (\%) & 113 & 83.8 & $62-73$ & $21-23$ \\
& EF (kg/h/year):males & 92.6 & 73.1 & $65-73$ & $21-23$ \\
& EF (kg/h/year):females & 59.7 & 48.3 & $47-56$ & \\
& EF (kg/h/year):young cattle & & & & \\
\end{tabular}

LW: liveweight; DMD: dry matter digestibility; EF: Emissions factor.

"Value excludes the positive effect of supplementation on diet digestibility in commercial production systems.

${ }^{1}$ Lima et al., 2002; ${ }^{2}$ Swammy \& Bhattacharya, 2006.

\section{Conclusion}

Cattle are a major source of methane emissions from the livestock sector in South Africa, contributing approximately $72.6 \%$ of the total livestock GHG emissions. Commercial beef cattle on veld are the major methane emitters, followed by emerging/communal beef cattle, dairy cattle and feedlot cattle. Dairy cattle are the major contributors to direct nitrous oxide emission from cattle. The methane emission factors calculated for commercial dairy and beef cattle production systems are more comparable to emission factors from developed countries (North America, Western Europe and Oceania) and the emerging/communal production systems to those of developing countries (Brazil and India). The IPCC default values for Africa underestimate emission factors across all cattle categories. The large variation in emission factors among countries and IPCC default values is primarily owing to differences in animal production systems, feed types and nutrient use efficiency by animals. This emphasizes the need to develop country-specific emission factors for enteric and manure emissions, as well as nitrous oxide emissions factors from manure through quantitative research.

\section{Acknowledgements}

This work is based on the research supported wholly by the National Research Foundation of South Africa and the RMRD SA. 


\section{References}

ANIR, 2009. Australian national greenhouse accounts: National Inventory Report. Department of climate change and energy efficiency, Australian National Inventory Report, Commonwealth of Australia, Canberra, ACT.

ANIR, 2010. Australian national greenhouse accounts: National Inventory Report. Department of climate change and energy efficiency, Australian National Inventory Report, Commonwealth of Australia, Canberra, ACT.

Bakker, H. \& Koops, W.J., 1978. An approach to the comparison of growth curves of Dutch Friesian, British Friesian and Holstein Friesian cows. In: Patterns of Growth and Development in Cattle. Eds: De Boer, H. \& Martin, J., Current Topics in Veterinary Medicine, vol 2. Springer Netherlands. pp. 705-915.

Banga, C.B., 2009. The development of breeding objectives for Holstein and Jersey cattle in South Africa. $\mathrm{PhD}$ thesis, University of the Free State, South Africa.

Blaxter, K.L. \& Clapperton, J.L., 1965. Prediction of the amount of methane production by ruminants. Br. J. Nutr. 19, 511-522.

Blignaut, J.N., Chitiga-Mabugu, M.R. \& Mabugu, R.M., 2005. Constructing a greenhouse gas inventory using energy balances: the case of South Africa 1998. J. Energy S. Afr. 16, 21-32.

Brouwer, E., 1965. Report of sub-committee on constants and factors. In: Proc $3{ }^{\text {rd }}$ Symp Energy Metab. Ed: Blaxter, K.L., London: Academic Press. pp. 441-443.

Chhabra, A., Manjunath, K.R., Panigrahy, S. \& Parihar, J.S., 2012. Greenhouse gas emissions from Indian livestock. Climate change, August, 2012.

De Waal, H.O., 1990. Animal production from native pasture (veld) in the Free State region - A perspective of the grazing ruminant. S. Afr. J. Anim. Sci. 20, 1-9.

DAFF, 2010. Livestock Population Statistics 2010. Department of Agriculture, Forestry and Fisheries, Pretoria.

DEAT, 2009. Greenhouse gas inventory, South Africa. Communication under the United Nation Framework Convention on Climate Change. Department of Environmental Affairs and Tourism, Pretoria, South Africa.

Dugmore, T.J. \& Du Toit, J.H., 1988. The chemical and nutritive value of kikuyu pasture. S. Afr. J. Anim. Sci. 18, 72-75.

Du Toit, C.J.L., Van Niekerk, W.A. \& Meissner, H.H., 2012. The carbon and water footprint of the South African livestock Industry. RMRD SA Project: Progress report. www.RMRDSA.co.za

Erasmus, L.J., 2009. Milk production from cows grazing kikuyu-ryegrass pastures. MSc thesis, University of Pretoria, South Africa.

Erasmus, L.J., Smith, W.A. \& Cronje, P.B., 2000. Feeding the lactating dairy cow to express its genetic potential. In: Dairy Herd Improvement in South Africa. Eds: Loubser, L.F.B., Banga, C.B., Scholtz, M.M. \& Hallowell, G.J., Agricultural Research Council, Animal Improvement Institute, Irene, South Africa.

FAO, 2006. Food and Agriculture Organization of the United Nations, 2010. [Accessed on 5 March 2012]. FAOSTAT.

Freer, M., Moore, A.D. \& Donnelly, J.R., 1997. GRAZEPLAN: Decision support systems for Australian grazing enterprises - II. The animal biology model for feed intake, production and reproduction and the grazfeed DSS. Agric. Syst. 54 (1), 77-126.

Gonzalez-Avalos, E. \& Ruiz-Suarez, L.G., 2001. Methane emission factors from cattle manure in Mexico. Biosecure Technol. 80 (1), 63-71.

Hegarty, R.S., Goopy, J.P., Herd, R.M. \& McCorkell, B., 2007. Cattle selected for lower residual feed intake have reduced daily methane production. J. Anim. Sci. 85, 1479-1486.

IPCC, 1997. IPCC Third Assessment Report: Climate change 2001 - The scientific basis. Contribution of Working Group I to the Third Assessment Report of the Intergovernmental Panel on Climate Change (IPCC). Eds: Houghton, J.T., Ding, Y., Griggs, D.J., Noguer, M., Van der Linden, P.J. \& Xiaosu, D., Cambridge University Press, UK.

IPCC, 2001. IPCC guidelines for National Greenhouse Gas Inventories, Prepared by the National greenhouse Gas Inventories Programme. Eds: Eggleston, H.S., Buendia, L., Miwa, K., Ngara, T. \& Tanabe, K., Published: IGES, Japan. 
IPCC, 2006. IPCC guidelines for National Greenhouse Gas Inventories, Prepared by the National greenhouse Gas Inventories Programme. Eds: Eggleston, H.S., Buendia, L., Miwa, K., Ngara, T. \& Tanabe, K., Published: IGES, Japan.

Kurihara, M., Magner, T., Hunter, R.A. \& McCrabb, G.J., 1999. Methane production and energy partition of cattle in the tropics. Br. J. Nutr. 81, 227-234.

LACTO data, 2010. Milk Producers Statistics, MPO, Vol 14 (1), Pretoria, South Africa.

Lima, M.A., Young Pessoa, M.C.P. \& Vieira Ligo, M.A., 2002. First Brazilian inventory of anthropogenic greenhouse gas emissions, background reports: Methane emissions from livestock. Ministry of Science and Technology, Brazil.

Loh, Z.M., Chen, D., Bai, M., Naylor, T., Griffith, D.W.T., Hill, J., Denmead, O.T., McGinn, S.M. \& Edis, R.B., 2008. Measurement of greenhouse gas emissions from Australian feedlot beef production using open path spectroscopy and atmospheric dispersion modelling. Aust. J. Exp. Agric. 48, 244-247.

McGinn, S.M., Flesh, T.K., Crenna, B.P., Beachemin, K.A. \& Coates, T., 2007. Quantifying ammonia emissions from a cattle feedlot using a dispersion model. J. Environ. Quality 36, 1858-1590.

Meeske, R., Rothauge, A., Van der Merwe, G.D. \& Greyling, J.F., 2006. The effect of concentrate supplementation on the productivity of grazing Jersey cows on a pasture based system. S. Afr. J. Anim. Sci. 36, 105-110.

Meissner, H.H., Hofmeyr, H.S., Van Rensburg, W.J.J. \& Pienaar, J.P., 1983. Classification of livestock for realistic prediction of substitution values in terms of biologically defined Large Stock Unit. Technical communication, Department of Agriculture, Pretoria, Republic of South Africa.

Mills, J.A., Dijkstra, J., Bannik, A., Cammell, S.B., Krebreab, E. \& France, J., 2001. A mechanistic model of whole tract digestion and methanogenesis in the lactating dairy cow: Model development, evaluation and application. J. Anim. Sci. 79, 1584-1597.

Minson, D.J. \& McDonald, C.K., 1987. Estimating forage intake from growth of cattle. Trop. Grassl., 21 (3), 116-121.

Moe, P.W. \& Tyrell, H.F., 1979. Methane production in dairy cows. J. Dairy Sci. 62, 1583-1586.

New Zealand Greenhouse Gas Inventory, 2010. Agricultural sector 1990 - 2010: A Pickering and S Wear, Ministry of Agriculture and forestry, Ministry of the environment, New Zealand. http://www.mte.govt.nz/publications/climate/greenhouse_gas_inventrory/2012/index.html.

O’Mara, F.P., 2011. The significance of livestock as a contributor to global greenhouse gas emissions today and in the near future. Anim. Feed Sci. Technol. 166-167, 7-15.

O’Reagain, P.J. \& Owen-Smith, R.N., 1996. Effects of species composition and sward structure on dietary quality in cattle and sheep grazing South African sourveld. J. Agric. Sci. 127, 261-270.

Otter, L., 2010. The South African agricultural GHG inventory for 2004. Department of Agriculture, Forestry and Fisheries, South Africa.

Penttilä, A., Slade, E.M., Simojoki, A., Riutta, T., Minkkinen, K. \& Roslin, T., 2013. Quantifying beetlemediated effects on gas fluxes from dung pats. PloS One 8 (8), 1-7.

SAFA, 2012. South African Feedlot Association - Report to authors on provincial cattle numbers in feedlots. SAFA, Centurion, South Africa.

SCA, 1990. Standing Committee on Agriculture - 'Feeding standards for Australian livestock, Ruminants', CSIRO Publications, Australia.

Scholtz, M.M., Steyn, Y., Van Marle-Köster, E. \& Theron, H.E., 2012. Improved production efficiency in cattle to reduce their carbon footprint for beef production. S. Afr. J. Anim. Sci. 42, 450-453.

Smith, B., 2006. Natural resources. In: The Farming Handbook. University of KwaZulu-Natal Press. South Africa.

Stats South Africa, 2010. Abstract of Agricultural Statistics, 2010. Directorate: Agriculture Statistics, DAFF, Pretoria, South Africa.

Swammy, M. \& Bhattacharya, S., 2006. Budgeting anthropogenic greenhouse gas emission from Indian livestock using country specific emission coefficients. Current Science 91 (10), 1340-1354.

Tainton, N.M., 1981. Veld Management in South Africa. Chapter 2: The ecology of the main grazing lands of South Africa. Pietermaritzburg: University of Natal Press, South Africa.

Tainton, N.M., 1999. Veld Management in South Africa. Chapter 2: The ecology of the main grazing lands of South Africa. Pietermaritzburg: University of Natal Press, South Africa.

Wasserman, J., 2005. Practical dairy tips. In: The Dairy Mail, February 2005, South Africa. 


\section{Appendix A}

Table A.1 Dairy cattle activity data: Total Mixed Ration (TMR)

\begin{tabular}{lcclc}
\hline Animal class & $\begin{array}{c}\text { Liveweight } \\
(\mathrm{kg})\end{array}$ & $\begin{array}{c}\text { Liveweight gain } \\
(\mathrm{kg} / \mathrm{day})\end{array}$ & $\begin{array}{c}\text { DMD } \\
(\%)\end{array}$ & $\begin{array}{c}\text { Crude protein } \\
\text { in feed (\%) }\end{array}$ \\
\hline Lactating cow & 590 & 0.1 & 76 & 17 \\
Lactating heifer & 503 & 0.55 & 76 & 17 \\
Dry cow & 590 & 0.1 & 60.3 & 13.5 \\
Pregnant heifer & 394 & 0.5 & 63 & 13.5 \\
Heifer > 1 year & 322 & 0.83 & 63 & 12 \\
Heifer 6 - 12 months & 172 & 0.78 & 68 & 16 \\
Heifers 2 - 6 months & 55 & 0.33 & 71 & 18 \\
Calves & 35 & 0.33 & 82 & 18 \\
& & & &
\end{tabular}

Table A.2 Dairy cattle activity data: pasture based

\begin{tabular}{|c|c|c|c|c|c|c|c|}
\hline \multirow{2}{*}{ Animal class } & \multirow{2}{*}{$\begin{array}{c}\text { Liveweight } \\
\text { (kg) }\end{array}$} & \multirow{2}{*}{$\begin{array}{c}\text { Liveweight gain } \\
\text { (kg/day) }\end{array}$} & \multicolumn{4}{|c|}{ DMD (\%)*^ } & \multirow{2}{*}{$\mathbf{C P}(\%)^{* \wedge}$} \\
\hline & & & Winter & Spring & Summer & Autumn & \\
\hline Lactating cow & 540 & 0.1 & 83 & 78 & 74 & 74 & 21.16 \\
\hline Lactating heifer & 438 & 0.35 & 83 & 78 & 74 & 74 & 21.16 \\
\hline Dry cow & 540 & 0.1 & 82 & 74 & 65.6 & 65.6 & 21.58 \\
\hline Pregnant heifer & 333 & 0.35 & 82 & 74 & 65.6 & 65.6 & 21.58 \\
\hline Heifer $>1$ year & 254 & 0.527 & 82 & 74 & 65.6 & 65.6 & 21.58 \\
\hline $\begin{array}{l}\text { Heifer } 6 \text { - } 12 \\
\text { months }\end{array}$ & 142 & 0.622 & 82 & 74 & 65.6 & 65.6 & 21.58 \\
\hline $\begin{array}{l}\text { Heifers } 2 \text { - } 6 \\
\text { months }\end{array}$ & 54 & 0.59 & 82 & 74 & 65.6 & 65.6 & 21.58 \\
\hline Calves & 36 & 0.30 & 82 & 74 & 65.6 & 65.6 & 21.58 \\
\hline
\end{tabular}

*Erasmus, L., 2009.

$\wedge$ Meeske et al., 2006.

DMD: dry matter digestibility.

CP: crude protein.

Table A.3 Manure management systems for dairy cattle in South Africa

\begin{tabular}{lccc}
\hline $\begin{array}{l}\text { Manure management system } \\
\text { (MMS) }\end{array}$ & $\begin{array}{c}\text { Methane conversion factor } \\
\text { (MCF, \%) }\end{array}$ & $\begin{array}{c}\text { TMR production system } \\
(\%)\end{array}$ & Pasture production system(\%) \\
\hline Lagoon & 90 & 10 & 3 \\
Liquid/slurry & 35 & 0.5 & 0 \\
Daily spread & 0.5 & 1.0 & 7 \\
Yielded at pasture & 1 & 88.5 & 90 \\
\hline
\end{tabular}

*MMS figures are based on DAFF (2009) data and expert assessments. 
Table A.4 Emission factors used in algorithms for nitrous oxide (ANIR, 2009)

\begin{tabular}{lc}
\hline Manure management systems (MMS) & $\begin{array}{c}\text { Emission factor } \\
\left(\mathbf{k g ~ N}_{2} \mathrm{O}-\mathrm{N} / \text { kg N excreted) }\right.\end{array}$ \\
\hline Lagoon & 0.001 \\
Liquid/ slurry & 0.001 \\
Daily spread & 0 \\
Pasture & 0 \\
Solid storage and drylot & 0.02 \\
Poultry manure with bedding & 0.02 \\
Poultry manure without bedding & 0.005 \\
Digester & 0.001 \\
\hline
\end{tabular}

Table A.5 Standard reference weight of dairy cattle

\begin{tabular}{lc}
\hline Animal class & Liveweight $(\mathrm{kg})$ \\
\hline Lactating cow & 580 \\
Lactating heifer & 580 \\
Dry cow & 580 \\
Pregnant heifer & 580 \\
Heifer > 1 year & 580 \\
Heifer 6 - 12 months & 580 \\
Heifers 2 - 6 months & 580 \\
Calves & 580 \\
\hline
\end{tabular}

\section{Appendix B}

Table B.1 Commercial cattle liveweights

\begin{tabular}{|c|c|c|c|c|c|}
\hline Animal Class & & Spring & Summer & Autumn & Winter \\
\hline \multirow[t]{2}{*}{ Bulls } & LW (kg) & 730 & 780 & 740 & 680 \\
\hline & LWG (kg) & 0.55 & 0.55 & -0.44 & -0.66 \\
\hline \multirow[t]{2}{*}{ Cows $>2$ year } & LW (kg) & 410 & 500 & 470 & 450 \\
\hline & LWG (kg) & 0.33 & 0.22 & -0.33 & -0.22 \\
\hline \multirow[t]{2}{*}{ Heifers } & LW (kg) & 300 & 350 & 390 & 420 \\
\hline & LWG (kg) & 0.22 & 0.55 & 0.44 & 0.33 \\
\hline \multirow[t]{2}{*}{ Ox } & LW (kg) & 350 & 420 & 470 & 480 \\
\hline & LWG (kg) & 0.6 & 0.77 & 0.55 & 0.11 \\
\hline \multirow[t]{2}{*}{ Young ox } & LW (kg) & 75 & 160 & 240 & 295 \\
\hline & LWG (kg) & 0.9 & 0.93 & 0.88 & 0.60 \\
\hline \multirow[t]{2}{*}{ Calves } & LW (kg) & 75 & 160 & 235 & 290 \\
\hline & LWG (kg) & 0.9 & 0.96 & 0.85 & 0.69 \\
\hline
\end{tabular}

LW: liveweight.

LWG: liveweight gain. 
Table B.2 Communal cattle liveweights

\begin{tabular}{|c|c|c|c|c|c|}
\hline Animal Class & & Spring & Summer & Autumn & Winter \\
\hline \multirow[t]{2}{*}{ Bulls } & LW (kg) & 460 & 500 & 468 & 420 \\
\hline & LWG (kg) & 0.44 & 0.44 & -0.35 & -0.53 \\
\hline \multirow[t]{2}{*}{ Cows $>2$ year } & LW (kg) & 364 & 380 & 356 & 340 \\
\hline & LWG (kg) & 0.27 & 0.18 & -0.27 & -0.18 \\
\hline \multirow[t]{2}{*}{ Heifers } & LW (kg) & 240 & 280 & 312 & 336 \\
\hline & LWG (kg) & 0.44 & 0.44 & 0.36 & 0.27 \\
\hline \multirow[t]{2}{*}{ Ox } & LW (kg) & 280 & 336 & 376 & 384 \\
\hline & LWG (kg) & 0.48 & 0.62 & 0.44 & 0.09 \\
\hline \multirow[t]{2}{*}{ Young ox } & LW (kg) & 60 & 128 & 192 & 236 \\
\hline & LWG (kg) & 0.74 & 0.76 & 0.71 & 0.49 \\
\hline \multirow[t]{2}{*}{ Calves } & LW (kg) & 60 & 128 & 188 & 232 \\
\hline & LWG (kg) & 0.71 & 0.76 & 0.67 & 0.49 \\
\hline
\end{tabular}

LW: liveweight.

LWG: liveweight gain.

Table B.3 Ratio of veld types per province

\begin{tabular}{llll}
\hline & Sweetveld & Sourveld & Mixed veld \\
\hline Western Cape & 0.5 & 0.3 & 0.2 \\
Northern Cape & 1 & 0 & 0 \\
Eastern Cape & 0.35 & 0.35 & 0.3 \\
Free State & 0.8 & 0.1 & 0.1 \\
KwaZulu-Natal & 0.2 & 0.6 & 0.2 \\
Mpumalanga & 0.15 & 0.7 & 0.15 \\
Limpopo & 0.6 & 0.2 & 0.2 \\
Gauteng & 0.2 & 0.6 & 0.2 \\
North West & 0.7 & 0.25 & 0.05 \\
& & &
\end{tabular}

Table B.4 Veld digestibilities (\%)

\begin{tabular}{lccc}
\hline & Sweetveld & Sourveld & Mixed veld \\
\hline Spring & 65 & 65 & 65 \\
Summer & 60 & 60 & 60 \\
Autumn & 55 & 50 & 50 \\
Winter & 50 & 45 & 45 \\
\hline
\end{tabular}

Veld: rangeland or natural pasture. 
Table B.5 Beef cattle: standard reference weight (ANIR, 2009)

\begin{tabular}{lc}
\hline Animal Class & $\begin{array}{c}\text { Standard reference weight } \\
(\mathbf{k g})\end{array}$ \\
\hline Bulls & 770 \\
Cows >2 year & 550 \\
Heifers & 550 \\
Ox & 660 \\
Young ox & 660 \\
Calves & 660 \\
\end{tabular}

\section{Appendix C}

Table C.1 Proportion of feedlot diet components in a total mixed ration

\begin{tabular}{lc}
\hline Feed component & Proportion \\
\hline Total grain & 0.779 \\
Other concentrates & 0.048 \\
Grasses & 0.138 \\
Legumes & 0.035 \\
\hline
\end{tabular}

Table C.2 Fraction of cellulose, hemicellulose, soluble residue and nitrogen in feedlot diet components

\begin{tabular}{|c|c|c|c|c|}
\hline \multirow{2}{*}{ Diet composition } & \multicolumn{2}{|c|}{ Concentrates } & \multicolumn{2}{|c|}{ Roughages } \\
\hline & Grain & Other concentrates & Grass & Legume \\
\hline Cellulose & 0.07 & 0.19 & 0.31 & 0.36 \\
\hline Hemicellulose & 0.04 & 0.11 & 0.31 & 0.20 \\
\hline Soluble residue & 0.68 & 0.019 & 0.21 & 0.21 \\
\hline Nitrogen & 0.02 & 0.05 & 0.026 & 0.032 \\
\hline
\end{tabular}

Table C.3 Feedlot cattle: liveweight (kg)

\begin{tabular}{|c|c|c|c|}
\hline Feedlot cattle class & $\begin{array}{c}\begin{array}{c}\text { Entry weight } \\
(\mathrm{kg})\end{array} \\
\end{array}$ & $\begin{array}{c}\text { Exit weight } \\
\text { (kg) }\end{array}$ & $\begin{array}{c}\text { Standard reference weight } \\
(\mathrm{kg})\end{array}$ \\
\hline Beef steer/ heifer & $220-250$ & 420 & 600 \\
\hline
\end{tabular}

